\title{
PRELIMINARY INVESTIGATIONS OF DISEASE-CAUSING ORGANISMS IN THE WHITE-CLAWED CRAYFISH AUSTROPOTAMOBIUS PALLIPES COMPLEX FROM STREAMS OF NORTHERN ITALY
}

\author{
F. QUAGLIO (1), C. MOROLLI (2), R. GALUPPI (3), C. BONOLI (3), F. MARCER (4), L. \\ NOBILE (5), G. DE LUISE (6), M.P. TAMPIERI (3).
}

1) Dipartimento di Sanità Pubblica, Patologia Comparata ed Igiene Veterinaria - Università degli Studi di Padova, Viale dell'Università, 16 - AGRIPOLIS - 35020 Legnaro, Padova, Italy; Francesco.quaglio@unipd.it

(2) Dipartimento di Scienze degli Alimenti - Università degli Studi di Bologna, Via S. Giacomo 9, 40126 Bologna, Italy.

(3) Dipartimento di Sanità Pubblica Veterinaria e Patologia Animale - Università degli Studi di Bologna, Via Tolara di Sopra 50, 40064 Ozzano dell'Emilia, Italy.

(4) Dipartimento di Scienze Sperimental Veterinarie - Università degli Studi di Padova, Viale dell'Università, 16 -AGRIPOLIS - 35020 Legnaro, Padova, Italy

(5) Ufficio Veterinario Adempimenti CEE. Emilia Romagna, Piazza dei Martiri 5, 40126 Bologna, Italy.

(6) Libero professionista - Consulente in acquacoltura, Via 24 maggio 61, Reana del Rojale 33010 (UD), Italy.

Reçu le 5 novembre 2004

Accepté le 23 janvier 2006

Received November 5, 2004

Accepted January 23, 2006

\begin{abstract}
A total of 99 live and 3 dead white-clawed crayfish Austropotamobius pallipes complex were collected during the summer and autumn of 2003 from one creek in Emilia Romagna region and four watercourses in Friuli Venezia Giulia region (Northern Italy) for experimental breeding and health status monitoring. Fifty-one animals from the Bidente River were maintained in tanks for breeding, and restocking, while another 30 specimens (27 living and 3 dead) were examined in the laboratory to evaluate their health status. Parasitological surveys were carried out on gills; mycological examinations on the exoskeleton (the walking legs and the abdomen); bacteriological examinations of inoculations from the haemolymph, and histopathological analysis on full transverse and sagittal sections of cephalothorax and abdomen.
\end{abstract}

In the branchial-chambers, the gill filaments and the exoskeleton were observed for ectocommensal peritrich protozoans Epystilis spp. and Cothurnia sieboldii. In crayfish sampled from five streams and rivers, Branchiobdella italica, B. astaci, B. parasita and $B$. hexodonta were isolated. Heavily damaged gills in the presence of branchiobdellid cocoons were observed in the crayfish found dead in Orvenco creek.

Hyaline and dematiaceous hyphomycetes were frequently observed and Fusarium spp. and Saprolegnia sp. were isolated from cuticular lesions.

Mortalities occurred in two tanks, after 2 and 4 weeks respectively, in the adult crayfish coming from Bidente River utilized for breeding, with approximately a $23.5 \%$ cumulative mortality rate. In both cases the crayfish were weak, anorexic and lethargic. 
Four and eight moribund samples respectively, coming from the two breeding tanks in which the mortalities occurred, underwent examination. In the first case the mortalities were attributed to Thelohania-like organisms and in the second case the mortalities were associated with enteric bacteria Citrobacter freundii.

Key-words: white-clawed crayfish, Austropotamobius pallipes complex, diseases, Northern Italy.

\section{INVESTIGATIONS PRÉLIMINAIRES SUR LES PATHOLOGIES DES ÉCREVISSES À PATTES BLANCHES AUSTROPOTAMOBIUS PALLIPES COMPLEX DANS DES COURS D'EAU DU NORD DE L'ITALIE}

\section{RÉSUMÉ}

Un total de 99 écrevisses à pattes blanches (Austropotamobius pallipes, complex) vivantes et 3 spécimens morts ont été capturés pendant l'automne 2003 dans un ruisseau de la région Emilia Romagna et dans quatre cours d'eau de Friuli Venezia Giulia au nord de l'Italie, pour faire de l'élevage expérimental et vérifier l'état de santé des populations.

51 individus du torrent Bidente ont été placés dans des réservoirs pour l'élevage, la reproduction et la réintroduction alors que les 30 autres écrevisses étaient examinées dans le laboratoire pour évaluer l'état de santé des populations.

Des tests parasitologiques ont été effectués sur les branchies. On a effectué des investigations mycologiques sur l'exosquelette, sur les membres et sur la cuticule abdominale; des examens bactériologiques sur l'hémolymphe et des analyses histopathologiques ont été faits sur des sections de céphalothorax et d'abdomen. Dans les appareils branchiaux, sur les filaments des branches et sur l'exosquelette ont été observés des protozoaires péritriches ectocommensaux d'Epystilis spp. et de Cothurnia sieboldii. Sur les écrevisses prélevées dans cinq torrents ont été isolés Branchiobdella italica, $B$. astaci, B. parasita and $B$. hexodonta. De graves dommages ont été notés sur les branchies en présence de branchiobdellae sur l'écrevisse morte du torrent Orvenco.

On a fréquemment observé des hyphomycètes hyalines et pigmentées et Fusarium spp. ainsi que Saprolegnia sp. ont été isolés sur des lésions cuticulaires.

Des mortalités d'écrevisses adultes ont été observées dans 2 réservoirs après 2 et 4 semaines, avec un pourcentage cumulé de mortalité de 23,5\% environ. Dans les 2 cas les écrevisses étaient anorexiques et léthargiques. 4 et 8 individus moribonds provenant des deux réservoirs d'élevage ont été examinés. La mortalité a été attribuée pour le $1^{\mathrm{er}}$ cas de mortalité à des microsporidioses d'organismes de type Thelohania, alors que pour le $2^{\mathrm{e}}$ cas la mortalité a été associée à des entérites bactériennes Citrobacter freundii.

Mots-clés: écrevisses à pattes blanches, Austropotamobius pallipes complex, pathologies, Italie du Nord.

\section{INTRODUCTION}

Native freshwater crayfish are threatened with extinction in Europe and in order to conserve and promote these legally protected resources, a number of measures must be taken (GHERARDI et al., 1999). In order to preserve the autochthonous species Austropotamobius pallipes complex, carefully planned restocking programmes are essential. Thus, the development of successful breeding techniques will be necessary to provide for the production of the young in captivity. An alternative action could be that of planning the transfer of crayfish from areas of plenty to those depleted. In any case, before 
starting a restocking plan, it is very important to evaluate the aquatic habitat conditions to ensure that the area can accept successfully the introduced crayfish. In addition, a plan needs to be developed for preventive disease control in order to avoid the loss of crayfish. Diseases can affect a population of crayfish and in turn adversely influence the targeted ecological system (UNESTAM, 1973).

Pathological investigations are essential both for obtaining information about the health status of wild populations and for guaranteeing the success of crayfish culturing by preventing the spread of diseases. The two most dangerous pathogenic groups are fungal and viral. Of these, the most virulent toward crayfish is the fungus, Aphanomyces astaci (Schikora), the agent of crayfish plague in European crayfish. Some authors have reported the association of an intranuclear bacilliform virus with the near extirpation of $A$. pallipes complex from the Nant watershed in France (EDGERTON et al., 2002a; EDGERTON, 2003; EDGERTON et al., 2004). A serious mortality in crayfish populations has often been attributed to pollution but without any proof, however, and the causative agent in many cases of mass mortality remains undiagnosed. Therefore it is of no surprise that less serious mortalities and chronic losses from crayfish populations are often inadequately investigated (ROGERS et al., 2003). As a result there are many gaps in our knowledge of crayfish pathology (VOGT, 1999), particularly in relation to the geographic distribution of the pathogens. So far Italy has been very fortunate as the incidence of crayfish diseases remains largely unknown.

The main purpose of this study was to evaluate the health status of some wild and cultured crayfish populations in Northern Italy. This base-line study is essential for scientifically monitoring these important crayfish populations and planning for their future.

\section{MATERIALS AND METHODS}

During the summer and early autumn of 2003 (June-October), a total of 102 whiteclawed crayfish, Austropotamobius pallipes complex, from wild populations were collected from streams in the regions of Emilia Romagna and Friuli Venezia Giulia (Northern Italy). The samples were collected from five different watercourses (Figure 1): the Bidente River (Forlì-Cesena Province, Emilia Romagna), and Chiarò, Orvenco, Rieca and Zamlin Creeks (Udine Province, Friuli Venezia Giulia). Crayfish were captured by hand or by means of baited traps. All of the live crayfish were rapidly transported to the laboratory in Bologna and placed in aquaria.

During the capture period, only three crayfish were found dead in three different streams (Bidente River, Orvenco and Rieca Creek); one of these crayfish (collected in Orvenco Creek) was immediately fixed in buffered formalin while the others were refrigerated. Five live crayfish were taken from each sampling site, except for the Bidente River (eight animals) and Zamlin Creek (four animals) and were sacrificed for pathological examination. The total of 27 samples was judged to be the minimum needed for an accurate survey picture, and therefore avoiding excessive collecting of wild crayfish (Table I). Fifty-one remaining captured adult crayfish coming from the Bidente River were placed in four tanks (Tank I-IV), each having a 40 I capacity, for experimental breeding. The density was $12-13$ subjects for each tank. The crayfish were maintained in the laboratory in well-aerated water at $15^{\circ} \mathrm{C}$, and fed twice a week with fragments of vegetables (potatoes and carrots) and fish pellets.

Disease outbreaks occurred in two tanks (II and III) 2 and 4 weeks respectively after being brought into the laboratory. In both cases, the affected crayfish were found to be anorexic, lethargic and having a weak tail-flick escape response. In the first episode (Tank II), 4 crayfish (33\%) were involved and in the second episode (Tank III), 8 crayfish $(61 \%)$ were affected. The moribund crayfish were collected and underwent parasitological, mycological, bacteriological and histopathological examinations. 


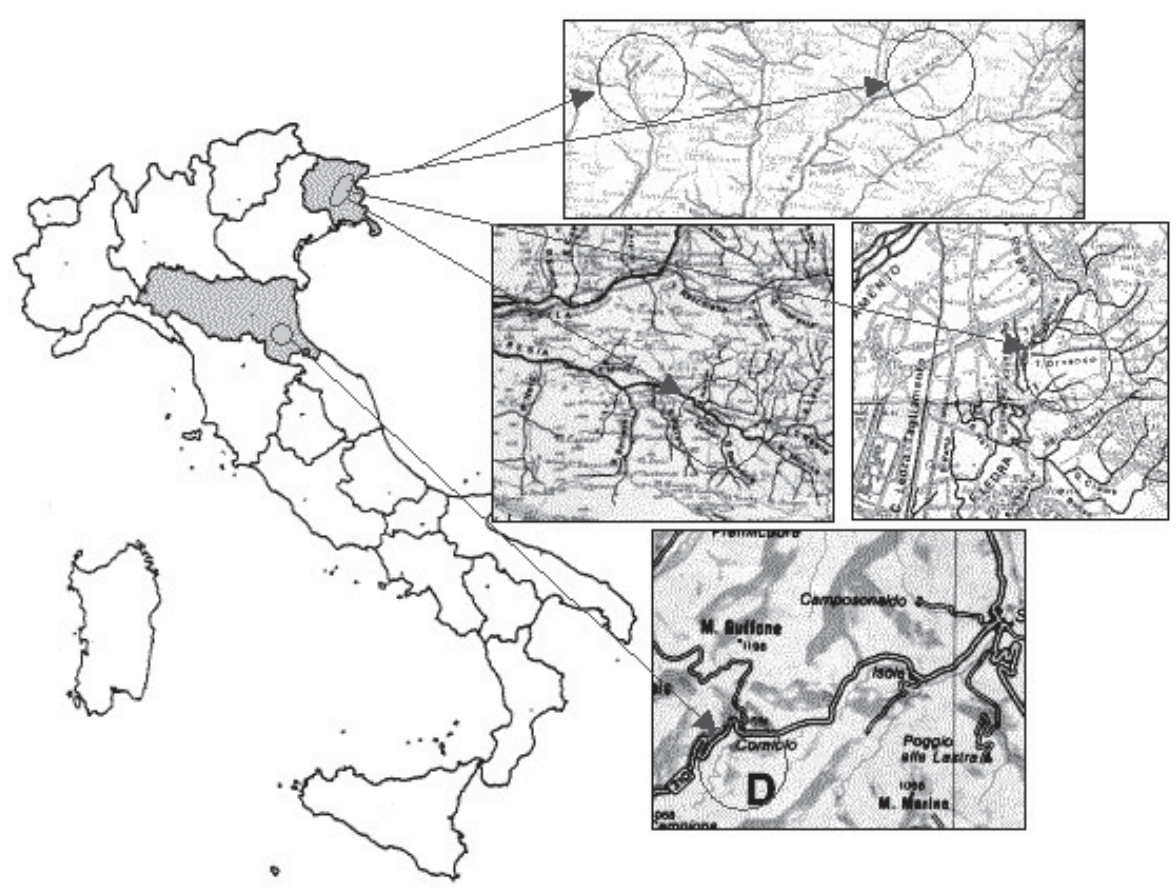

Figure 1

Location of sampling sites.

Figure 1

Localisation des sites de prélèvement.

\section{Parasitological investigations}

Preparations of wet smears from the lesions and gills of each crayfish were examined under the bright field microscope (Total magnifications 100x and 400x). Individual protozoans were identified using standard keys (MATTHES and GUHL, 1973; KUDO, 1977). In addition, branchiobdellidans were found, removed from each crayfish, fixed in $70 \%$ ethanol and were then counted and clarified with lactophenol. The branchiobdellidans were stained with Borax Carmine and mounted with Glycerine Jelly or Hoyer's fluid. All of the branchiobdellidans were examined and measured using the optical microscope. Identification of the specimens was made on the basis of the jaws, the spermatheca and spermathecal duct morphology using identification keys (MOSZYNSKI, 1938; POP, 1965; M.A.F.F., 1986; GELDER et al., 1994).

\section{Mycological investigations}

Small pieces (1-2 $\left.\mathrm{mm}^{2}\right)$ and melanized patches of the exoskeleton were removed from the abdomen and legs of 41 crayfish, rinsed in sterile distilled water, placed on plates containing glucose-yeast extract agar (MIN et al., 1994) with penicillin $\mathrm{G}\left(6 \mathrm{mg} \mathrm{l}^{-1}\right)$ and oxolinic acid $\left(10 \mathrm{mg} \mathrm{l}^{-1}\right.$ ) (ALDERMAN and POLGLASE, 1986), and incubated at $26^{\circ} \mathrm{C}$. The colonies found growing on agar were examined macro- and microscopically, using bright field illumination, for identification. Moulds were identified to genus using morphological features, i.e. colony appearance, hyphae, sexual and/or asexual reproduction (BARRON, 1968; ST-GERMAIN and SUMMERBELL, 1996; DE HOOG and GUARRO, 1996), and yeasts by means of the Auxonographic gallery API 20c Aux (Biomerieux). When the colonies had tubular, variably branched, very poorly septate, hyphae (looking like oomycetes), they were placed in sterile distilled water with and without hemp seeds at $18^{\circ} \mathrm{C}$ and $26^{\circ} \mathrm{C}$, to develop sporangia and/or sexual structures. 
Table I

Origin of captured crayfish and samples undergoing pathological examination.

Tableau I

Provenance des écrevisses capturées et échantillonnées pour des investigations sanitaires.

\begin{tabular}{|c|c|c|c|c|c|c|c|c|}
\hline \multirow[b]{2}{*}{$\begin{array}{l}\text { Rivers and } \\
\text { Creeks }\end{array}$} & \multicolumn{2}{|c|}{$\begin{array}{l}\text { Captured } \\
\text { crayfish }\end{array}$} & \multicolumn{2}{|c|}{$\begin{array}{c}\text { Samples undergoing } \\
\text { examination }\end{array}$} & \multicolumn{4}{|c|}{ Types of examination } \\
\hline & 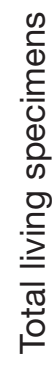 & 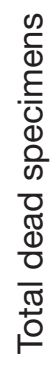 & 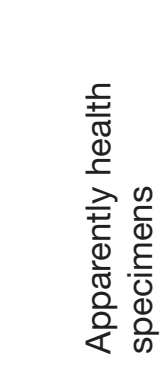 & 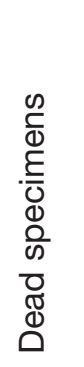 & $\begin{array}{l}\bar{\pi} \\
. \overline{0} \\
\frac{0}{0} \\
+\frac{1}{0} \\
\mathbb{0} \\
0 \\
0\end{array}$ & 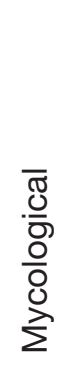 & 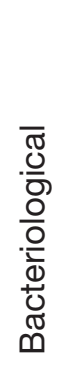 & 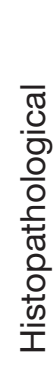 \\
\hline Bidente & 59 & 1 & 8 & 1 & & 9 & 2 & 9 \\
\hline Chiarò & 5 & 1 & 5 & 1 & 6 & 6 & 2 & 6 \\
\hline Rieca & 23 & - & 5 & - & 5 & 5 & 2 & 5 \\
\hline Orvenco & 8 & 1 & 5 & 1 & 5 & 5 & 2 & 6 \\
\hline Zamlin & 4 & - & 4 & - & 4 & 4 & 2 & 4 \\
\hline Total & 99 & 3 & 27 & 3 & 29 & 29 & 10 & 30 \\
\hline
\end{tabular}

\section{Bacteriological investigations}

Bacteriological analysis was performed on a total of 22 crayfish. Samples of $0.1 \mathrm{ml}$ of hemolymph were taken from the pericardial sinus of each crayfish using $1 \mathrm{ml}$ sterile syringes, inoculated on Blood Agar and incubated at $25^{\circ} \mathrm{C}$ for $24-48$ hours. Subcultures were then incubated on Blood Agar, MacConkey Agar and TCBS (Thiosulphate Citrate Bile Salts) plates, respectively. The identification of the isolates was carried out using the commercial miniaturized API 20E and API 20 NE Systems (BioMerieux, France), and also mobility, oxidase, catalase and $\mathrm{O} / \mathrm{F}$ tests.

\section{Histopathological investigations}

Portions of gills, abdominal muscle and the entire cephalothorax were taken from each of the 27 crayfish and fixed in $10 \%$ buffered formalin (for at least 24 hours), trimmed into microcassettes and embedded in paraffin wax for histological examination. Sections of $5 \mu \mathrm{m}$ were stained with haematoxylin and eosin, PAS and Giemsa (EDGERTON, 2004).

\section{RESULTS}

\section{Parasitological investigation}

The parasites and epicommensal organisms taken from the white-clawed crayfish are summarized in Table II. Peritrichous ciliate Cothurnia sieboldii (Figure 2) were found 
on crayfish from all water courses, while Epistylis spp. showed a lower infestation rate. In histological examination, externally, the most frequently observed organisms were C. sieboldii on healthy exoskeleton. Colonies of these ciliates tended to concentrate in protected cuticular folds on the exoskeleton and cephalothorax (Figure 3), and in the gill

\section{Table II}

Results of parasitological examinations- no. positives (\%).

Tableau II

Résultats des observations parasitologiques - nombre de cas positifs (\%).

\begin{tabular}{|c|c|c|c|c|c|c|c|}
\hline $\begin{array}{l}\text { Origin of } \\
\text { crayfish } \\
\text { (river, } \\
\text { creek, } \\
\text { tanks) }\end{array}$ & 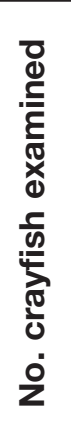 & 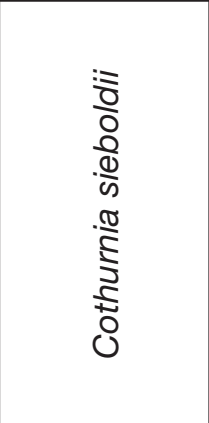 & 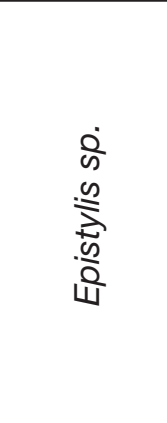 & $\begin{array}{l}\delta \\
\delta \\
0 \\
0\end{array}$ & 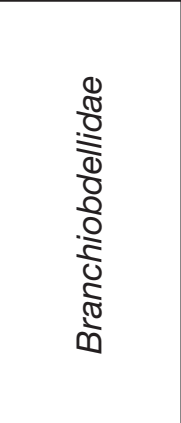 & 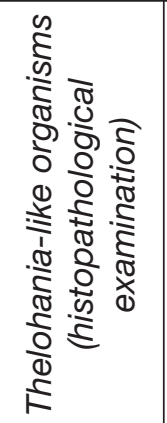 & 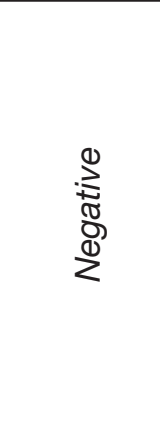 \\
\hline Bidente & 9 & 7 (77.7\%) & $1(11.1 \%)$ & $1(11.1 \%)$ & $1(11.1 \%)$ & 0 & $1(11.1 \%)$ \\
\hline Chiarò & 6 & $5(83.3 \%)$ & 0 & $1(16.7 \%)$ & $1(16.7 \%)$ & 0 & $1(16.7 \%)$ \\
\hline Rieca & 5 & $4(80.0 \%)$ & 0 & $3(60.0 \%)$ & $2(40.0 \%)$ & 0 & $1(20.0 \%)$ \\
\hline Orvenco & 5 & $3(60,0 \% \%)$ & 0 & $2(40.0 \%)$ & $1(20.0 \%)$ & 0 & $1(20.0$ \\
\hline Zamlin & 4 & 3 (75.0\%) & $1(25.0 \%)$ & $1(25.0 \%)$ & $1(25.0 \%)$ & 0 & $1(25.0 \%)$ \\
\hline Tank II & 4 & $4(100 \%)$ & 0 & $1(25.0 \%)$ & $2(50.0 \%)$ & $4(100 \%)$ & 0 \\
\hline Tank III & 8 & $8(100 \%)$ & $3(37.5 \%)$ & $2(25.0 \%)$ & 0 & 0 & 0 \\
\hline Total & 41 & 34 (82.9\%) & $5(12.2 \%)$ & $\begin{array}{c}12 \\
(29.3 \%) \\
\end{array}$ & $8(19.5 \%)$ & $4(9,8 \%)$ & $5(12.2 \%)$ \\
\hline
\end{tabular}

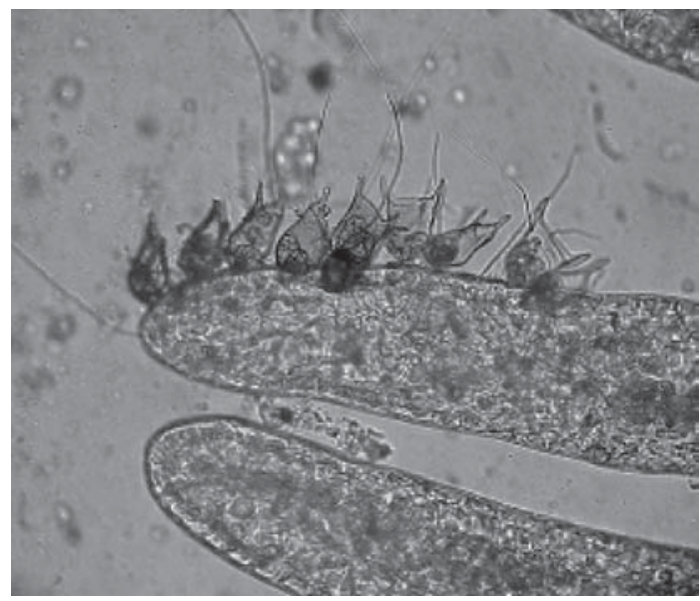

Figure 2

Loricate ciliophora Cothurnia sieboldii attached to the gill filaments of whiteclawed crayfish Austropotamobius pallipes complex.

Figure 2

Loricate ciliophora Cothurnia sieboldii attaché sur les filaments des branchies d'écrevisses à pattes blanches Austropotamobius pallipes complex. 


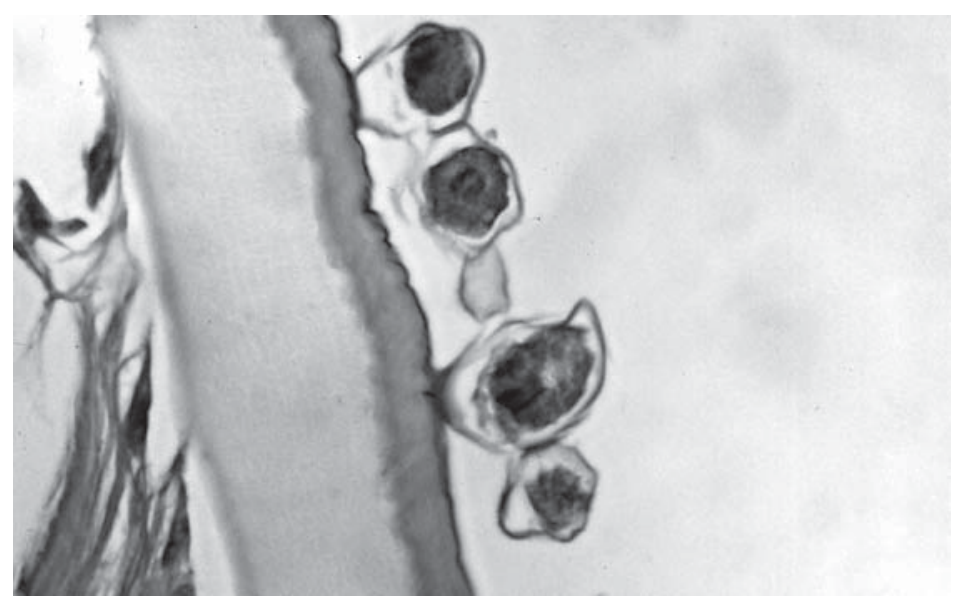

\section{Figure 3}

Cross-section of the exoskeleton of the cephalothorax of A.pallipes complex with loricate ciliophora Cothurnia sieboldii attached to the surface. There is no penetration of the host cuticle or any host tissue response - HE.

\section{Figure 3}

Sections d'exosquelette de céphalothorax d'A. pallipes complex avec Loricate ciliophora Cothurnia sieboldii. H.E. II n'y a pas de pénétration de la cuticule de I'hôte, ni de réaction tissulaire de l'hôte.

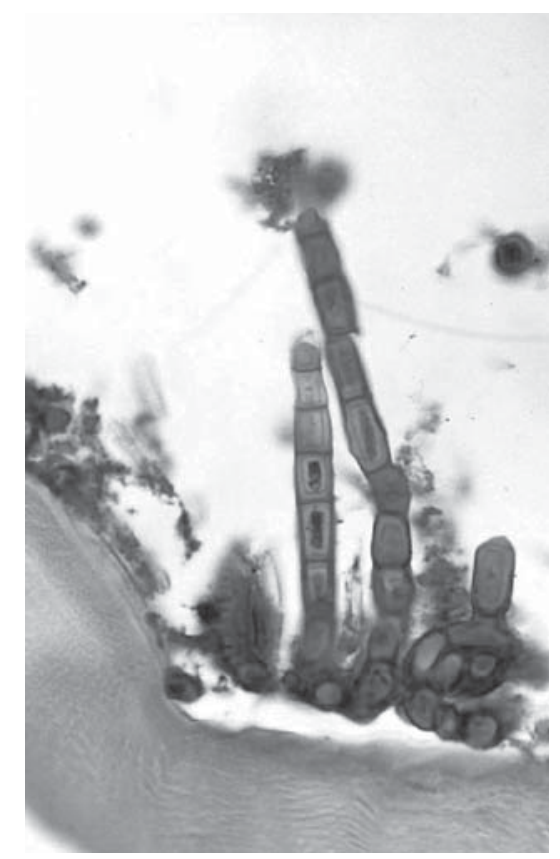

\section{Figure 4}

Septate hyphae on the cuticle of the exoskeleton in association with detritus and bacteria - PAS.

\section{Figure 4}

Hyphes cloisonnés dans la cuticle de l'exosquelette en association avec les détritus et les bactéries - PAS. 
chamber particularly in well-sheltered areas, such as at the base of gill filaments. When peritrichous ciliates were located in the deeper portions of the gill chamber, they appeared to trap debris and bacteria.

Branchiobdellidans were found on crayfish from all the sites being on the gills and exoskeleton. The percentage of the branchiobdellidan species isolated in whiteclawed crayfish from the different streams are shown in Table III. The species found were: Branchiobdella italica in crayfish from the Bidente River, Zamlin Creek and Rieca Creek, $B$. astaci in samples from Chiarò and Orvenco Creeks, $B$. parasita in crayfish from Orvenco Creek and B. hexodonta from Rieca Creek. Both adults of B. astaci and B. parasita and numerous cocoons were present on the gills of crayfish coming from Orvenco Creek (Figure 5). In the dead crayfish from Orvenco Creek, during microscopical and histopathological examinations, the gill filaments were observed to be heavily damaged with melanization and partical amputations (Figures 6 and 7). Only cocoons were found on 2 crayfish coming from the Bidente Creek and maintained in Tank III. The number of branchiobdellidans on a host varied greatly depending on the locality.

\section{Table III}

Species of Branchiobdellidae found on crayfish coming from various sources. In the Table, the specimens from Tank II have been included together with the samples from the Bidente river, because they came from the same source.

Tableau III

Espèces de branchiobdellidae trouvées sur des écrevisses d'origines diverses. Dans le tableau les échantillons du réservoir. Ils ont été mis avec ceux de la rivière Bidente, car ils ont la même provenance.

\begin{tabular}{|c|c|c|c|c|c|c|c|c|}
\hline \multirow{3}{*}{$\begin{array}{l}\text { Origin of } \\
\text { crayfish (river, } \\
\text { creek, tanks) }\end{array}$} & \multirow{3}{*}{ 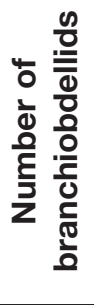 } & $\begin{array}{c}B . \\
\text { hexodonta }\end{array}$ & \multicolumn{3}{|c|}{ B. italica } & B. astaci & \multicolumn{2}{|c|}{ B. parasita } \\
\hline & & $\begin{array}{l}\text { Dental } \\
\text { formulas }\end{array}$ & \multicolumn{3}{|c|}{ Dental formulas } & $\begin{array}{c}\text { Dental } \\
\text { formulas }\end{array}$ & \multicolumn{2}{|c|}{ Dental formulas } \\
\hline & & $\begin{array}{l}6 \\
5\end{array}$ & $\begin{array}{l}5 \\
5\end{array}$ & $\begin{array}{l}6 \\
5\end{array}$ & $\begin{array}{l}6 \\
6\end{array}$ & $\begin{array}{l}1 \\
1\end{array}$ & $\begin{array}{|lll|}3 & 1 & 3 \\
3 & 1 & 3\end{array}$ & $\begin{array}{lll}2 & 1 & 2 \\
2 & 1 & 2\end{array}$ \\
\hline Bidente/Tank II & 73 & 0 & $\begin{array}{c}25 \\
(34.2 \%)\end{array}$ & $\begin{array}{c}45 \\
(61.6 \%)\end{array}$ & $\begin{array}{c}3 \\
(4.2 \%)\end{array}$ & 0 & 0 & 0 \\
\hline Chiarò & 1 & 0 & 0 & 0 & 0 & $1(100 \%)$ & 0 & 0 \\
\hline Rieca & 9 & $5(55.6 \%)$ & $\begin{array}{c}2 \\
(22.2 \%)\end{array}$ & $\begin{array}{c}2 \\
(22.2 \%)\end{array}$ & 0 & 0 & 0 & 0 \\
\hline Orvenco & 15 & 0 & 0 & 0 & 0 & $8(53.3 \%)$ & $\begin{array}{c}1 \\
(6.7 \%)\end{array}$ & $\begin{array}{c}6 \\
(40.0 \%)\end{array}$ \\
\hline Zamlin & 10 & 0 & $\begin{array}{c}2 \\
(20.0 \%)\end{array}$ & $\begin{array}{c}8 \\
(80.0 \%) \\
\end{array}$ & 0 & 0 & 0 & 0 \\
\hline Total & 108 & $5(4.6 \%)$ & $\begin{array}{c}29 \\
(26.9 \%)\end{array}$ & $\begin{array}{c}55 \\
(50.9 \%)\end{array}$ & $\begin{array}{c}3 \\
(2.8 \%)\end{array}$ & 9 (8.3\%) & $\begin{array}{c}1 \\
(0.9 \%)\end{array}$ & $\begin{array}{c}6 \\
(5,6 \%)\end{array}$ \\
\hline
\end{tabular}




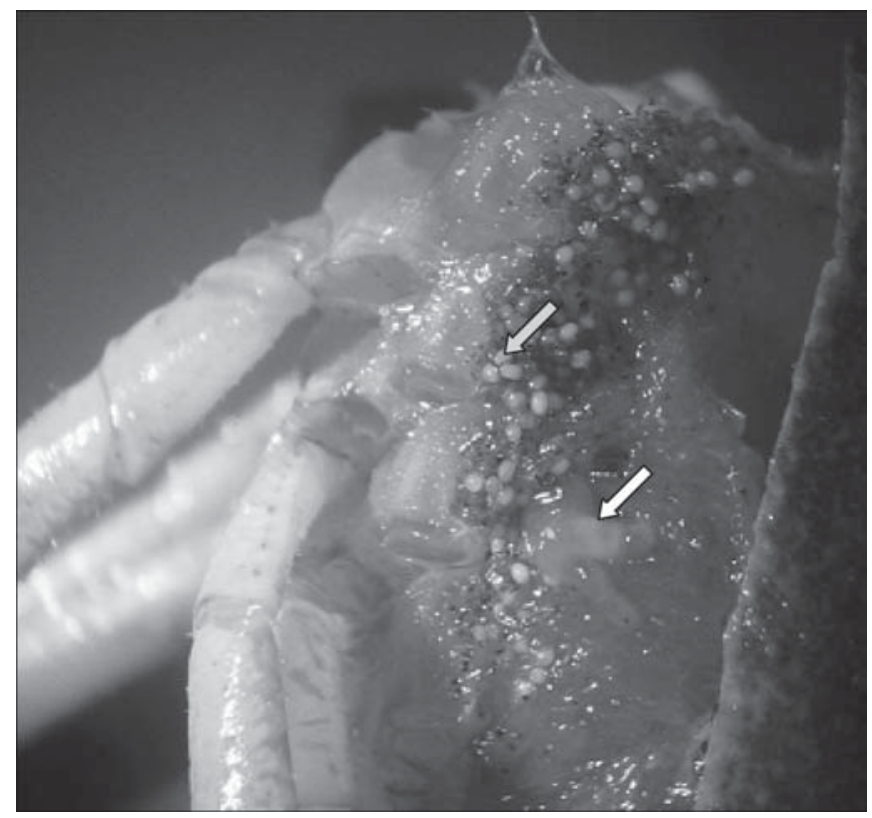

Figure 5

A. pallipes complex with heavy gill infestation by cocoons (green arrow) and adults (white arrow) of Branchiobdella astaci and B. parasita.

\section{Figure 5}

A. pallipes complex avec infestation d'œufs (flèche vert) et d'adultes (flèche blanc) de Branchiobdella astaci et B. parasita.

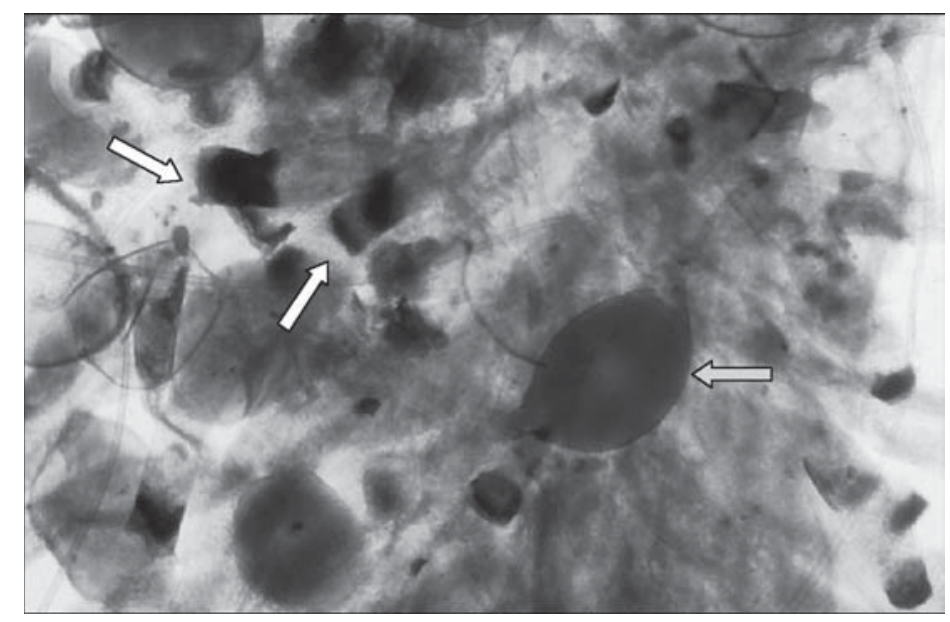

\section{Figure 6}

Microscopic observation of $A$. pallipes complex gills with amputation of the filaments (white arrows) and intense melanisation (brown areas) near the spawned cocoon (green arrow) of branchiobdellids.

Figure 6

Observation microscopique des branchies de $A$. pallipes complex avec amputations des filaments (flèches blanc) et mélanisation intense près des œufs (flèche vert) des branchiobdellids. 


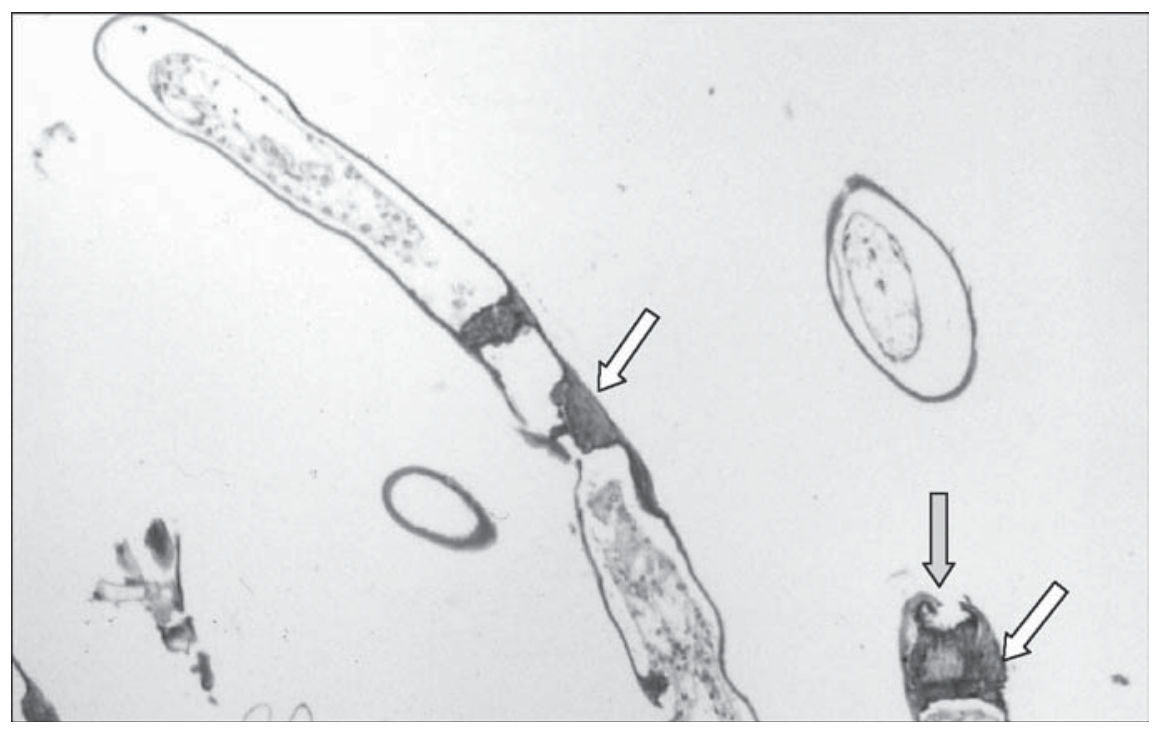

Figure 7

Histological cross-section of gills of the same crayfish represented in Figure 3 and 4, showing gill tip removal (green arrow) and melanisation (white arrows) - H.E.

\section{Figure 7}

Sections des branchies de l'écrevisse des Figures 3 et 4 avec des dommages (flèche vert) et mélanisation (flèches blanc) - H.E.

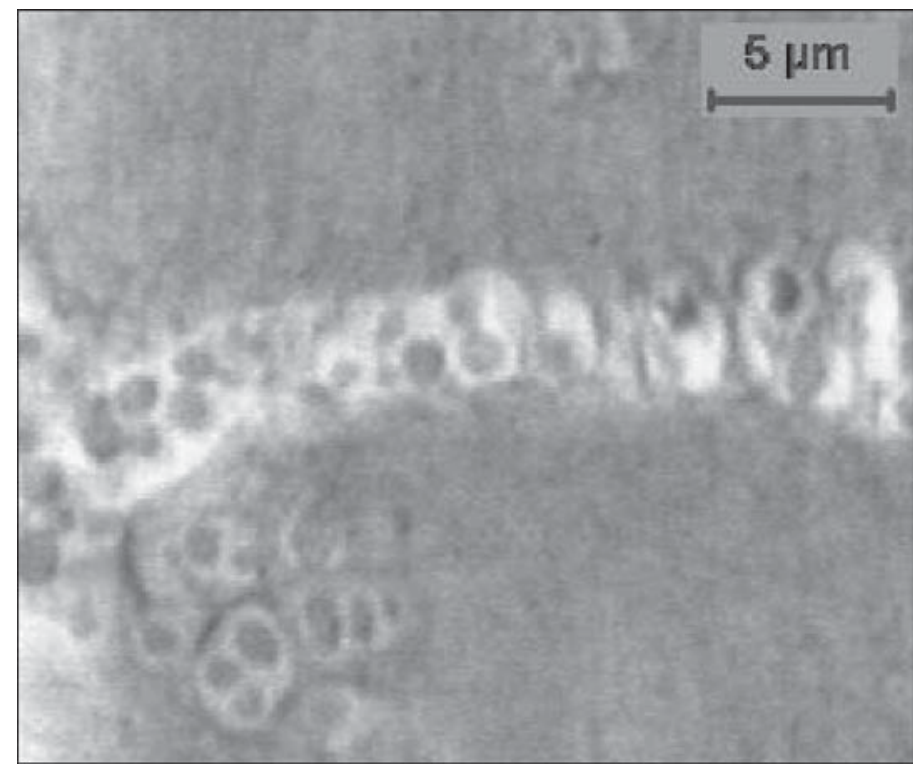

\section{Figure 8}

A. pallipes complex. Immature spores attributed to a microsporidium Thelohanialike organism infiltrating the skeletal muscle - H.E.

Figure 8

A. pallipes complex. Spores immatures attribués à un organisme proche du microsporidium Thelohania- "like" infiltrant le muscle squelettique - H.E. 
During the first episode of mortalities in Tank II, at the histological examinations, the skeletal muscles of the cephalothorax and the legs were found to show liquefactive necrosis; they had been replaced by masses of spores in different stages of development and variable in size, attributed to a microsporidian Thelohania-like organism (Figure 8). Early infections of the muscle of $A$. pallipes complex examined, with small spore masses developing within the hosts' sarcoplasm, induced no inflammatory response, as observed by LANGDON (1991) in microsporidiosis of marron (Cherax tenuimanus); while in advanced developmental stages with dispersion of spore, phlogosis was rarely observed. In one of these crayfish, the cardiac muscle exhibited diffused infiltration of the spores with necrosis and a scarce presence of granulocytes while the gills presented focal diffusions of microsporidians.

\section{Mycogical investigation}

Fungi were isolated from both the abdominal cuticle and the legs, and the results are summarised in Table IV. Some hyaline (Trichoderma spp, Acremonium spp., Fusarium spp. and Aspergillus spp.) and dematiaceous (Alternaria spp.) hyphomycetes were found on the abdomen and/or legs. Among the mycetes, Fusarium sp. was the most frequently isolated being found on $19.5 \%$ of the abdomens and $7.3 \%$ of the legs examined. Most of these crayfish were healthy and without apparent lesions. Fusarium sp. was isolated from cuticular lesions on one female crayfish from the Bidente River which also exhibited ulcers on the exoskeleton of the abdomen and had large colonies of Epystilis sp. on the gills and body surface. At the histological examination of crayfish coming from bidente river,

\section{Table IV}

Results of mycological investigations: no. positives (\%).

Tableau IV

Résultats des investigations mycologiques: n.positives (\%).

\begin{tabular}{|c|c|c|c|c|c|c|c|c|c|c|c|}
\hline \multirow{2}{*}{$\begin{array}{c}\begin{array}{c}\text { Origin } \\
\text { of } \\
\text { crayfish }\end{array} \\
\text { (river, } \\
\text { creek, } \\
\text { tanks) }\end{array}$} & \multirow{2}{*}{ 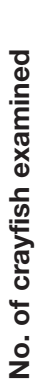 } & \multicolumn{5}{|c|}{ Abdominal cuticle } & \multicolumn{5}{|c|}{ Legs } \\
\hline & & 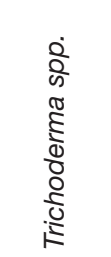 & 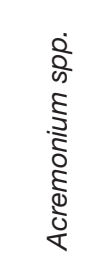 & 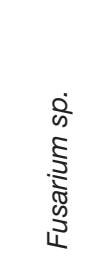 & 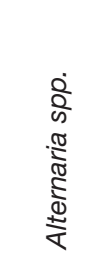 & 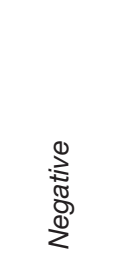 & 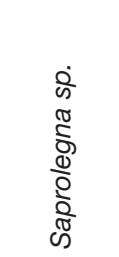 & 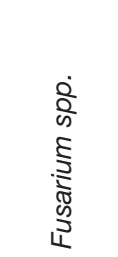 & 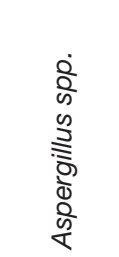 & 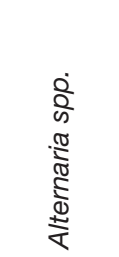 & 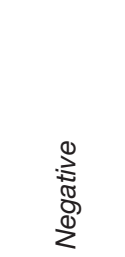 \\
\hline Bidente & 9 & $\begin{array}{c}1 \\
\text { (11.1\%) }\end{array}$ & $\begin{array}{c}1 \\
(11.1 \%)\end{array}$ & $\begin{array}{c}1 \\
(11.1 \%)\end{array}$ & $\begin{array}{c}1 \\
(11.1 \%)\end{array}$ & $\begin{array}{c}5 \\
(54.6 \%)\end{array}$ & 0 & $\begin{array}{c}1 \\
(11.1 \%)\end{array}$ & 0/ & $\begin{array}{c}1 \\
(11.1 \%)\end{array}$ & $\begin{array}{c}7 \\
(77.8 \%)\end{array}$ \\
\hline Chiarò & 6 & $\begin{array}{c}1 \\
(16.7 \%)\end{array}$ & 0 & $\begin{array}{c}1 \\
(16.7 \%)\end{array}$ & 0 & $\begin{array}{c}4 \\
(66.6 \%)\end{array}$ & 0 & 0 & 0 & $\begin{array}{c}1 \\
(16.7 \%)\end{array}$ & $\begin{array}{c}5 \\
(83.3 \%)\end{array}$ \\
\hline Rieca & 5 & 0 & 0 & $\begin{array}{c}3 \\
(60.0 \%)\end{array}$ & 0 & $\begin{array}{c}2 \\
(40.0 \%)\end{array}$ & 0 & 0 & 0 & 0 & $\begin{array}{c}5 \\
(100.0 \%)\end{array}$ \\
\hline Orvenco & 5 & 0 & 0 & $\begin{array}{c}2 \\
(40.0 \%)\end{array}$ & 0 & $\begin{array}{c}3 \\
(60.0 \%)\end{array}$ & $\begin{array}{c}1 \\
(20.0 \%)\end{array}$ & $\begin{array}{c}1 \\
(20.0 \%)\end{array}$ & 0 & 0 & $\begin{array}{c}3 \\
(60.0 \%)\end{array}$ \\
\hline Zamlin & 4 & 0 & 0 & $\begin{array}{c}1 \\
(25.0 \%)\end{array}$ & 0 & $\begin{array}{c}3 \\
(75.0 \%)\end{array}$ & 0 & I & 0 & 0 & $\begin{array}{c}4 \\
(100.0 \%)\end{array}$ \\
\hline Tank II & 4 & 0 & 0 & 0 & $\begin{array}{c}2 \\
(50.0 \%)\end{array}$ & $\begin{array}{c}2 \\
(50.0 \%)\end{array}$ & 0 & $\begin{array}{c}1 \\
(25.0 \%)\end{array}$ & $\begin{array}{c}1 \\
(25.0 \%)\end{array}$ & 0 & $\begin{array}{c}2 \\
(50.0 \%)\end{array}$ \\
\hline Tank III & 8 & $\begin{array}{c}1 \\
\text { (12.5\%) }\end{array}$ & 0 & 0 & 0 & $\begin{array}{c}7 \\
(87.5 \%)\end{array}$ & 0 & 0 & 0 & 0 & $\begin{array}{c}8 \\
(100.0 \%)\end{array}$ \\
\hline TOTAL & 41 & $\begin{array}{c}3 \\
(7.3 \%)\end{array}$ & $\begin{array}{c}1 \\
(2.5 \%)\end{array}$ & $\begin{array}{c}8 \\
(19.5 \%)\end{array}$ & $\begin{array}{c}3 \\
(7.3 \%)\end{array}$ & $\begin{array}{c}26 \\
(63.4 \%)\end{array}$ & $\begin{array}{c}1 \\
(2,5 \%)\end{array}$ & $\begin{array}{c}3 \\
(7.3 \%)\end{array}$ & $\begin{array}{c}1 \\
(2.5 \%)\end{array}$ & $\begin{array}{c}2 \\
(4.8 \%)\end{array}$ & $\begin{array}{c}34 \\
(82.9 \%)\end{array}$ \\
\hline
\end{tabular}


PAS positive septate hyphae on the exoskeleton were often observed in the presence of melanized areas and in association with detritus and bacteria accumulations (Figure 4).

From the melanized areas of the exoskeleton and legs on one crayfish coming from Orvenco Creek, a mycete with coenocytic thallus was isolated. This, when transplanted onto hemp seed, produced abundant clavate, pyriform or irregular gemmae, single, or frequently, catenulate. Cylindrical, clavate or irregular straight zoosporangia were abundant. The strain failed to produce a sexual form at either $18^{\circ} \mathrm{C}$ or $26^{\circ} \mathrm{C}$. The characteristics of secondary cysts were not observed. Based on morphological features, the isolates were assigned to the genus Saprolegnia, but further identification was not carried out to the species level.

\section{Bacteriological investigation}

The results of the bacteriological examinations are summarised in Table V. Aeromonas hydrophila was present in the hemolymph of $50 \%$ of the healthy crayfish taken from Zamlin Creek.

Citrobacter freundii was found in $87.5 \%$ of the moribund crayfish from Tank III; in these specimens histological examination revealed bacteria in the lumen of the hepatopancreatic tubules, often adhering to the surface of the epithelium. Hepatopancreocytes were more cuboidal than columnar in shape (Figure 9). Multifocal desquamation of degenerated epithelial cells was also observed. Similarly, in some samples the midgut and midgut caecum had focal necrosis. Focal haemocytic infiltrates were found in the haemal spaces adjacent to these necrotic areas and were accompanied by the melanization of the necrotic areas in more advanced stages. In later stages, multifocal granulomas were observed, characterized by central debris inclusive of bacteria, a surrounding amorphous melanin capsule and an outer cellular capsule composed of concentric haemocytes and fibroblasts (Figure 10).

\section{Table V}

Results of bacteriological examinations: no. positives (\%).

\section{Tableau V}

Résultats des investigations bactériologiques: n.positives (\%).

\begin{tabular}{|c|c|c|c|c|c|}
\hline $\begin{array}{l}\text { Origin of crayfish } \\
\text { (river, creek, tanks) }\end{array}$ & 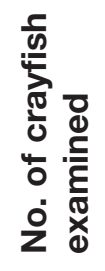 & 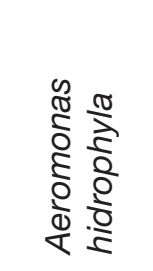 & 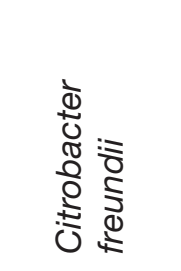 & 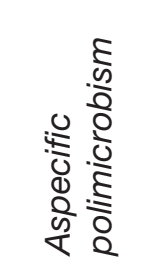 & 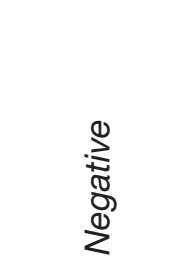 \\
\hline Bidente & 2 & 0 & 0 & 0 & 2 (100\%) \\
\hline Chiarò & 2 & 0 & 0 & $1(50 \%)$ & 1 (50\%) \\
\hline Rieca & 2 & 0 & 0 & 0 & $2(100 \%)$ \\
\hline Orvenco & 2 & 0 & 0 & 0 & $2(100 \%)$ \\
\hline Zamlin & 2 & 1 (50\%) & 0 & 0 & 1 (50\%) \\
\hline Tank II & 2 & 0 & 0 & 0 & $2(100 \%)$ \\
\hline Tank III & 8 & 0 & 7 (87.5\%) & 0 & $1(12.5 \%)$ \\
\hline TOTAL & 22 & $1(4.5 \%)$ & 7 (31.9\%) & $1(4.5 \%)$ & $13(59.1 \%)$ \\
\hline
\end{tabular}




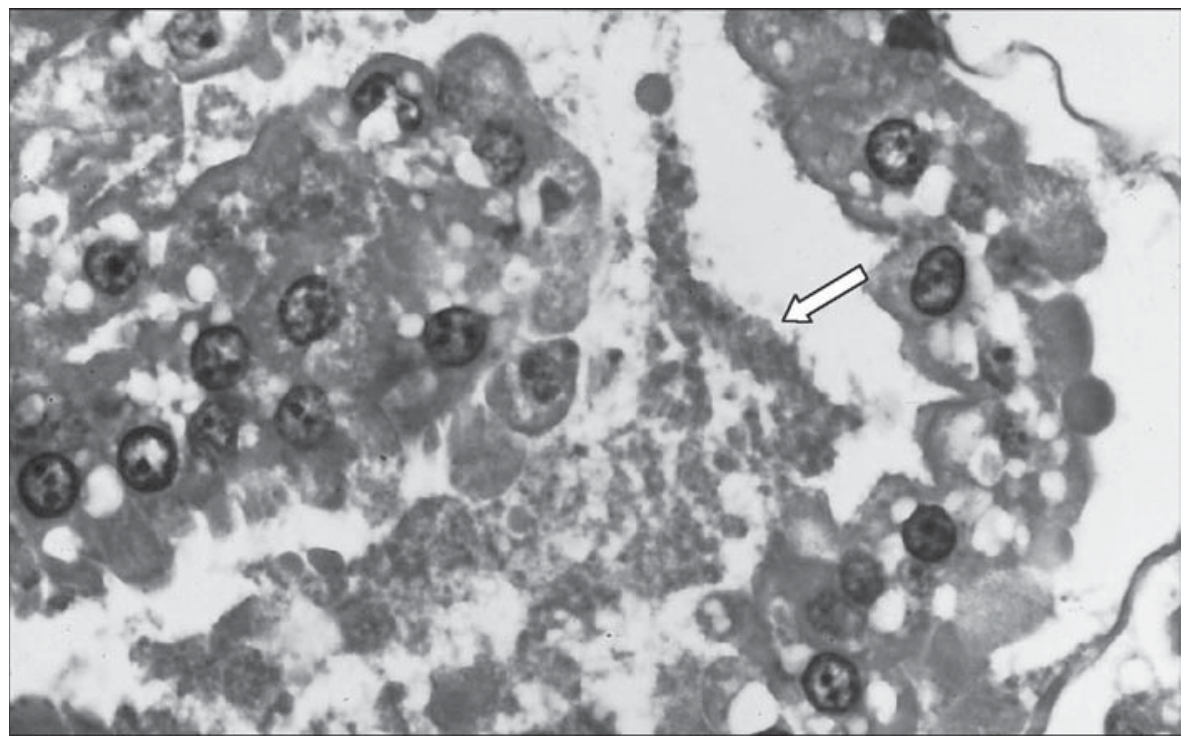

Figure 9

Light micrograph of enteric bacterial infection in $A$. pallipes complex. Hepatopancreocytes are more cuboidal than columnar in shape. Bacterial aggregates (arrow) are present in the lumen of the tubule and adhering to the surface of the epithelium - H.E.

Figure 9

Infection bactérienne entérique chez $A$. pallipes complex. Les hépatopancréocytes sont plus cuboidaux que colomnaires. Les agrégats bactériens (flèche) sont présents en lumen du tubule et adhérents sur la surface de l'épithélium - H.E.

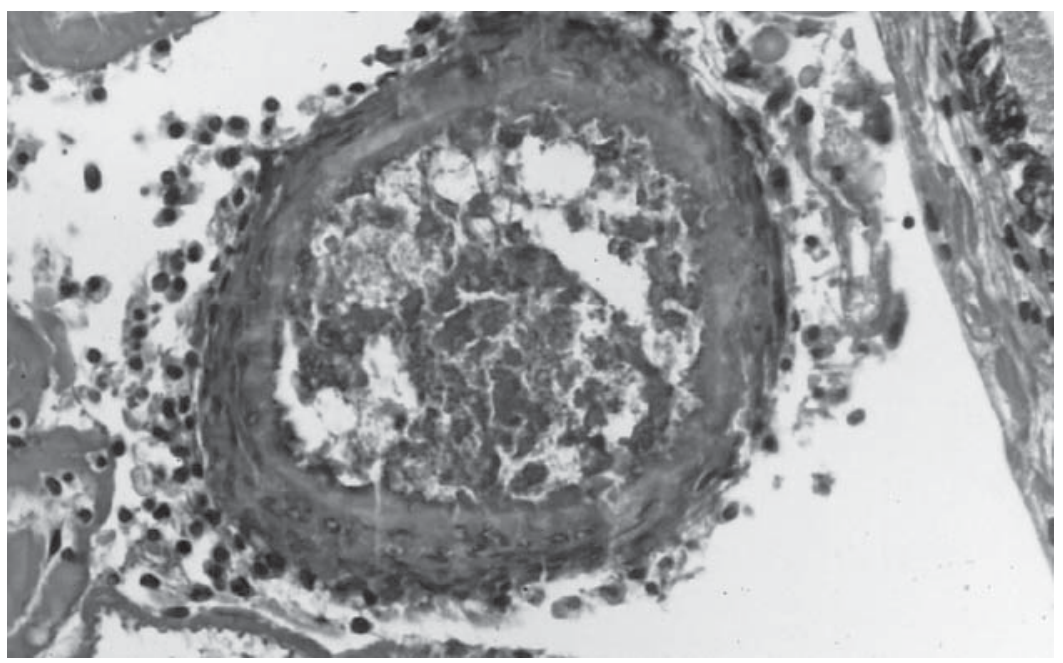

Figure 10

Light micrograph of enteric bacterial infection in $A$. pallipes complex. Hepatopancreatic granuloma - H.E.

Figure 10

Infection bactérienne entérique dans un granuloma hépatopancréatique de A. pallipes complex- H.E. 


\section{DISCUSSION}

\section{Epicommensal protozoans}

A variety of protozoa moves about or attach to the body surface and gills of crayfish (JOHNSON, 1983). Ectocommensal infestation of the gills and exoskeleton of the crayfish examined in this study was common, but no detrimental effects on crayfish health were observed. In another study, carried out on red swamp crayfish (Procambarus clarkii), we found that the elevated presence of Epistylis spp. was associated with low dissolved oxygen concentration and high organic pollution (QUAGLIO et al., 2004). The low incidence of Epistylis spp. in A. pallipes complex examined could be related to the optimal environmental conditions and water quality they experience. MATTHES and GUHL (1973) have reported Cothurnia sieboldii also as a commonly occurring species on European crayfish.

\section{Branchiobdellidans}

In a recent paper, according to GELDER (1999), branchiobdellidans are defined as ectosymbionts and not parasites. In our investigation, the presence of heavy infestation by $B$. astaci and $B$. parasita and their cocoons were associated with severe lesions in the gills of the dead crayfish from Orvenco Creek suggesting a deleterious activity during spawning of these branchiobdellids. In such a situation, the hosts are continually debilitated by the loss of blood (VEY, 1981; ALDERMAN and POLGLASE, 1988) with the risk of attachment and entry of potential bacterial and mycotic pathogens through damaged tissue. The presence of melanized areas was not surprising since, in invertebrates, mechanical injuries or the presence of foreign objects, such as parasites and microorganisms result in melanin deposition around the damaged tissue or the intruding object (CERENIUS and SÖDERHÄLL, 2004). We have not found any gill lesions on crayfish in presence of $B$. italica and $B$. hexodonta.

\section{Thelohania-like organism}

Spore size in histological sections can vary and it is therefore not appropriate to place taxonomic emphasis on such morphometrics (EDGERTON and ORWENS, 1999); for this reason we prefer define the detected pathogen organism as Thelohania-like.

The life cycles of crayfish microsporidians is not well understood (EDGERTON et al., 2002b). The presence of a microsporidian parasite of the genus Thelohania in northwestern Italy was observed and described for the first time in the region of Liguria by MORI and SALVIDIO (2000). The infection rates can also vary at different localities in the wild (QUILTER, 1976). However, the rate of infestation of the pathogens in the crayfish living in Bidente River is not easy to detect, as these crayfish, at the time of the capture showed no clinical evidence of infection, either externally or through histopathological study for microsporidians.

The clinical symptoms appeared in a very advanced state of infection (after two weeks of maintenance in laboratory tank), when loss of muscle function was caused by the masses of spores within the muscle fibres, according to OIDTMANN et al. (1996). The decreased locomotory activity may reduce the feeding ability of infected individuals. The end result of the infection is the massive breakdown of the host muscle tissue and a consequent loss of muscular power. COSSINS and BOWLER (1974) maintained infected crayfish in the laboratory for several months without any dramatic deterioration in their condition. The rapid evolution of the pathology in our case could have been induced by the stress conditions of the artificial environment, such as overcrowding, a low level of dissolved oxygen and temperature fluctuations. 
The possibility of the development of a high rate of microsporidiosis infection in cultured crayfish populations emphasizes the need for careful management of crayfish farms. In aquaculture, this disease can reach a prevalence rate of roughly $30 \%$, and thus, can cause considerable financial losses (SCHÄPERCLAUS et al., 1990; VEY, 1986; VOGT, 1999). The paucity of knowledge about this potentially significant disease highlights the need for further research to be conducted on both hosts and parasites, in order to develop effective measures for preventing the occurrence and spread of microsporidiosis in a developing industry.

\section{Fungi}

The mycetes of the genera Acremonium, Alternaria, Aspergillus and Trichoderma are found in healthy crayfish and can be considered naturally occurring saprophytes, often associated with poor water quality. These form epifloral colonies and do not destroy the cuticle.

Fusarium spp. have been shown to be a problem in marine shrimp and lobster as well as in their freshwater relatives (JOHNSON, 1983). Fusarium solani is described as the cause of brown abdomen disease and fungal infection in the gills of $A$. leptodactylus and A. pallipes (CHAIN and VEY, 1988; MAESTRACCI and VEY, 1988). In our study, Fusarium $\mathrm{sp}$. was the most frequently isolated member among the mycetes. It was frequently found on healthy crayfish without apparent lesions; thus it could be considered as a saprophyte or a superficial contaminant. Fusarium sp. was isolated from lesions in only one female crayfish coming from the Bidente River which also exhibited ulcers in the exoskeleton of the abdomen.

Saprolegnia spp. are water mould, now classified in the kingdom Protoctista, phylum Heterokonta, class Oomycotea (BRUNO and WOOD, 1999), and include species which are responsible for significant infections involving both living and dead fish. The identification of these species, by cultural and microscopic methods, is based on obtaining the sexual structures in vitro (oogonia, antheridia and oospores). However, one problem facing the diagnostic mycologist when culture conditions fail to stimulate the production of sexual structures, making accurate identification of the species becomes very difficult (PICKERING and WILLOUGHBY, 1982).

Secondary zoospore cyst ornamentation features are also used by many investigators to identify cultures of Saprolegnia from fish and crayfish when examined using electron microscopy or phase contrast light microscopy (PICKERING et al, 1979; HALLET and DICK, 1986; SÖDERHÄLL et al., 1991). Recently, molecular studies were also carried out based on these features (MOLINA et al., 1995; DIÉGUEZ-URIBEONDO et al., 1996). In the strain of Saprolegnia we isolated, only asexual reproduction had occurred and so, as we not observed the characteristic of secondary cysts and not performed molecular studies, we were unable to determine the species.

As pointed out by SÖDERHÄLL et al., (1991), although S. parasitica causes a severe problem in fish, it does not appear to be an important parasite for crayfish. However, during intensive culture of crayfish, Saprolegnia spp. may cause some mortality, especially in females with eggs; furthermore DIÉGUEZ-URIBEONDO et al., (1994), in a challenge test with zoospores, infected healthy (non-injured) Astacus astacus, Pacifastacus leniusculus and Procambarus clarkii inducing a $20 \%$ mortality. When the epicuticle of the crayfish was abraded before challenge, the mortality increased significantly by threefold. Predisposing factors are probably needed to allow the manifestation of the mould pathogenic activity. Our strain was isolated from the melanized areas of the exoskeleton and from the legs of one crayfish but their pathogenic role, primary or secondary, is not clear. 


\section{Bacteria}

Asymptomatic bacteraemia was reported in apparently healthy freshwater crayfish by SCOTT and THUNE (1986) and OIDTMANN and HOFFMANN (1999). Aeromonas hydrophila is a ubiquitous and opportunistic bacterium which comprises a portion of the normal microbial flora of fish as well as other aquatic animals. This microrganism is present in all freshwater environments and in brackish water and can be isolated from water having a wide range of physical-chemical limits $\left(\mathrm{pH} 5.2-9.8\right.$; temperature from $10^{\circ} \mathrm{C}$ to $45^{\circ} \mathrm{C}$ ) and in both oligosaprobiotic and polysaprobiotic ecosystems. Some strains of A. hydrophila are capable of causing illness in fish, amphibians, higher vertebrates and aquatic invertebrates. The role of $A$. hydrophila in the pathological processes of crayfish remains unclear. We hypothesized that disease is only likely to occur when the host is stressed by unfavourable environmental conditions, such as overcrowding and abnormal feeding (QUAGLIO et al., 2002).

In relation to the bacteriological isolation of Citrobacter freundii, this bacterium is considered a common component of the aquatic microflora and the intestinal flora of freshwater crayfish (VOGT, 1999). They show typical opportunistic behaviour and may have pathogenic effects on the host, sometimes resulting in heavy mortality (QUAGLIO et al., 2002). Citrobacter sp. was described to have moderate pathogenicity for Austropotamobius pallipes, causing slow infections when ingested in high doses. (VEY et al., 1975). Moreover, C. freundi was reported to be responsible for bacterial enteritis (EDGERTON et al., 2002b).

Mortalities associated with enteric bacteria from the crayfish gut have been described in several species of European and North American crayfish (TOUMANOFF 1965; TOUMANOFF, 1966; BOEMARE and VEY, 1977; OIDTMANN and HOFFMANN, 1999; EVANS and EDGERTON, 2000; EDGERTON et al., 2002b).

Infectivity trials with a strain of Citrobacter freundii caused lesions in normal crayfish force-fed large inoculums but the overall infectivity of bacterial isolates was low (BOEMARE and VEY, 1977). The authors suggested that disease is only likely to occur when the host is stressed by unfavourable environmental conditions. This could explain the pathologic episode which occurred in the experimental tank and appropriate measures must be taken in culture facilities to avoid the insurgence of this disease.

\section{CONCLUSIONS}

The populations of white-clawed crayfish sampled during the survey live in a very good habitat in favourable environmental conditions far from agricultural intensive culture, buildings and alien crayfish. The Bidente was chosen as an example of a river with an abundant population of crayfish, at least in the upper part of the course which is in a national nature reserve. For this reason, in our examinations, the health status of crayfish in the wild was generally satisfying. Opportunistic pathogens and symbionts were frequently observed in crayfish in the wild and in captivity. Therefore, particular care must be paid crayfish culture to prevent environmental stressors causing disease outbreaks.

The presence of the native white-clawed crayfish has been greatly and progressively reduced in number in recent years in many European geographic areas. Thus, this species risks extinction. This is in a result of epizootic diseases, the introduction of alien species, changes in the habitat brought by excavation, work on river-beds and streams and general industrialisation which very often occurs in areas near the course of the rivers. In Italy, we have never found the crayfish plague in native crayfish species but other devastating causes are inducing the decline of some stocks. Crayfish mortality can be graphic evidence of a serious chemo-physical problem in lakes or streams. The impact of toxic 
and harmful substances (fertilisers, herbicides) and of industrial and agricultural pollution on white-clawed crayfish has not been sufficiently evaluated and needs further study. The frequent monitoring of pathogen and environmental conditions are essential to detect and solve problems before significant mortality occurs.

Monitoring of the sanitary conditions in developing crayfish farms and investigations about the health status of wild populations are very important practices and must be implemented in order to manage this culturally and economically significant but vulnerable resource.

\section{ACKNOWLEDGEMENTS}

The study was supported by grants from Ministero delle Politiche Agricole e Forestali - VI Piano Triennale della Pesca e dell'Acquacoltura. The authors wish to acknowledge Dr. Gerald Goldsmith for reviewing the English form and the generous support of Mrs. Patrizia de Matteo.

\section{REFERENCES}

ALDERMAN D.J., POLGLASE J.L., 1986. Aphanomyces astaci. Isolation and culture. Journal of Fish Disease 9, 367-379.

ALDERMAN D.J., POLGLASE J.L., 1988. Pathogens, parasites and commensals. In: HOLDICH, D.M., LOWERY, R.S. (Eds.), Freshwater Crayfish: Biology, Management and Exploitation. Croom Helm, Sydney, pp. 167-212.

BARRON G.L., 1968. The Genera of Hyphomycetes from soil. The Williams \& Wilkins Company, Baltimora, USA

BOEMARE N., VEY A., 1977. Étude des souches bactériennes isolées d'écrevisses Atlantoastacus pallipes Lereboullet atteintes de septicémies et d'affections hépatointestinales. Annales Hydrobiologiques, 8 (2), 153-162.

BRUNO D.W., WOOD B.P., 1999. Saprolegnia and other oomycetes. In Wood P.T.K and Bruno D.W. (Eds). Fish diseases and disorders Vol. 3: Viral, Bacterial and Fungal Infections. CAB International Publishing, Wallingford, UK, 1999.

CERENIUS C., SÖDERHÄLL K., 2004. The prophenoloxidase- activating system in invertebrates. Immunological Reviews, 198, 116-126.

CHINAIN M., VEY A., 1988. Experimental study of Fusarium solani: infections in Astacus leptodactylus and Pacifastacus leniusculus (Crustacea, Decapoda) Diseases of Aquatic Organisms, 5, 215-223.

COSSINS A.R., BOWLER K., 1974. An histological and ultrastructural study of Thelohania contejeani Henneguy, 1892 (Nosematidae), microsporidian parasite of the crayfish Austropotamobius pallipes Lereboullet. Parasitology, 68, 81-91.

DE HOOG G.S., GUARRO J., 1996. Atlas of Clinical Fungi. Centralbureau voor Schimmelcultures/Universitat Rovira I Virgili, Baarrn and Delft, The Netherlands.

DIÉGUEZ-URIBEONDO J., CERENIUS L., SÖDERHÄLL K., 1994. Saprolegnia parasitica and its virulence on three different species of freshwater crayfish. Aquaculture, 120, 219-228.

DIÉGUEZ-URIBEONDO J., CERENIUS L., SÖDERHÄLL K., 1996. Physiological characterization of Saprolegnia parasitica isolates from brown trout. Aquaculture, $140,247-257$. 
EDGERTON B.F., 2003. Further studies reveal that A. pallipes bacilliform virus (ApBV) is common in populations of native crayfish in south-eastern France. Bulletin of the European Association of Fish pathologists, 23, 7-12.

EDGERTON B.F., 2004. Diseases of freshwater crayfish.

EDGERTON B.F., ORWENS L., 1999. Histopathological surveys of the redclaw freshwater crayfish, Cherax quadricarinatus, in Australia. Aquaculture, 180, 23-40.

EDGERTON B.F., WATT H., BECHERAS J.M., BONAMI J.R., 2002a. An intranuclear bacilliform virus associated with near extirpation of Austropotamobius pallipes Lereboullet from the Nant watershed in Ardèche, France. Journal of Fish Disease, $25,523-531$.

EDGERTON B.F., EVANS L.H., STEPHENS F.J., OVERSTREET R.M., 2002b. Synopsis of freshwater crayfish diseases and commensal organisms. Review Article. Aquaculture, 206, 57-135.

EDGERTON B.F., HENTTONEN P., JUSSILA J., MANNONEN A., PAASONEN P., TAUGBØL T., EDSMAN L., SOUTY-GROSSET C., 2004. Understanding the causes of disease in European freshwater crayfish. Conservation Biology, 18 (6) 1466-1474.

EVANS L.H., EDGERTON B.F., 2000. Pathogens, parasites and commensals. In HOLDICH D.M. (Ed). Biology of freshwater crayfish. Blackwell Science, Oxford. ISBN 0-63205431-X, pp. 377-438.

GELDERS.R., 1999. Zoogeography of branchiobdellidans (Annelida) and temnocephalidans (Platyhelminthes) ectosymbiotic on freshwater crustaceans, and their reactions to one another in vitro. Hydrobiologia, 406, 21-31.

GELDER S.R., DELMASTRO G.B., FERRAGUTI M., 1994. A report on branchiobdellidans (Annelida: Clitellata) and a taxonomic key to the species in northern Italy, including the first record of Cambarincola mesochoreus on the introduced American red swamp crayfish. Boll. Zool., 61, 179-183.

GHERARDI F., BALDACCINI N., BARBARESI S., ERCOLINI P., DE LUISE G., MAZZONI D., MORI M., 1999. Case studies of alien crayfish in Europe. The situation in Italy. In: GHERARDI F. and HOLDICH D.M. (Eds), Crayfish in Europe as alien species. How to make the best of a bad situation? A. A. Balkema, Rotterdam. pp. 107-128. ISBN 9054104694.

HALLETT I.C., DICK M.W., 1986. Fine structure of zoospore cyst ornamentation in the Saprolegniaceae and Pythiaceae. Transaction of the British Mycological Society, 86, 457-463.

JOHNSON P.T., 1983. Diseases caused by viruses Rickettsiae, Bacteria and Fungi. In Provenzano A.J. (Ed) The biology of crustacea: pathobiology. Academic Press NY, p. 1-78.

KUDO R.R., 1977. Protozoology. Charles C. Thomas, Springfield II, pp. 1174.

LANGDON J.S., 1991. Microsporidiosis due to a pleistophorid in marron, Cherax tenuimanus (Smith), (Decapoda: Parastacidae). Journal of Fish Disease, 14, 33-44.

MATTHES D., GUHL W., 1973. Sessile ciliaten der Flusskrebse. Protistologica, IX (4), 459-470.

MINISTERY OF AGRICULTURE, FISHERIES AND FOOD, 1986. Manual of veterinary parasitological laboratory techniques, Reference Book 418, HMSO, London.

MIN H.K., HATAI K., BAI S., 1994. Some inhibitory effects of chitosan on fish-pathogenic oomycete, Saprolegnia parasitica. Fish pathology, 29 (2), 73-77. 
MAESTRACCI V., VEY A., 1988. Fungal infection of gills in crayfish: Histological, cytological and physiopathological aspects of the disease. Freshwater crayfish, 7, 187-194.

MOLINA F.I., JONG S.C., MA G., 1995. Molecular characterization and identification of Saprolegnia by restriction analysis of genes coding for ribosomal RNA. Antoine van Leeuwenhoek, 68, 65-74.

MOSZYNSKI A., 1938. Quelques remarques sur les Branchiobdellidae européens. Annales Musei Zoologici Polonici, XIII (9), 89-103.

MORI M., SALVIDIO S., 2000. The occurrence of Thelohania contejeani Henneguy, a microsporidian parasite of the crayfish Austropotamobius pallipes (Lereboullet), in Liguria Region (NW Italy). Journal of Limnology, 59 (2), 167-169.

OIDTMANN B., HOFFMANN R.W., 1999. Bacteriological investigations on crayfish. Freshwater Crayfish, 12, 288-302.

OIDTMANN B., EL-MATBOULI M., FISCHER H., HOFFMANN R., KLARDING K., SCHMID I., SCHMIDT R., 1996. Light microscopy of Astacus astacus L. under normal and selected pathological conditions, with special emphasis to porcelain disease and crayfish plague. Freshwater Crayfish, 11, 465-480.

PICKERING A.D. WILLOUGHBY L.G., 1982. Saprolegnia infections of salmonid fish. In: Roberts R.J. (ed) Microbial diseases of fish, Society for general microbiology, 9. Academic Press, London, pp. 271-297.

PICKERING A.D., WILLOUGHBY L.G., McCRORY C.B., 1979. Fine structure of secondary zoospore cyst cases of Saprolegnia isolates from infected fish. Transaction of the British Mycological Society, 72, 427-436.

POP V., 1965. Systematische Revision der europäischen Branchiobdelliden (Oligochaeta). Zool. Gb. Syst. Bd., 92, 219-238.

QUAGLIO F., RUBINI S., MANFRIN A., NOBILE L., DELGADO M.L., MAXIA M., MOROLLI C. GALUPPI R., FIORAVANTI M.L., 2002. Bacteriological investigation on allochthonous crayfish in Northern Italy. Freshwater Crayfish, 13, 280-286.

QUAGLIO F., MOROLLI C., GALUPPI R., TAMPIERI M.P., MARCER F., ROTUNDO G., 2004. Pathological investigation on crayfish (Procambarus clarkii, Girard 1852) from canals in Padana Plain. XV Symposium of the International Association of Astacology. London, 29 March-2 April 2004. Book of the Abstracts, p. 45.

QUILTER C.G., 1976. Microsporidian parasite Thelohania contejeani Henneguy from New Zealand freshwater crayfish. New Zealand Journal of Marine and Freshwater Research, 10, 225-231.

ROGERS D., HOFFMAN R., OIDTMANN B., 2003. Diseases in selected Austropotamobius pallipes populations in England. In: HOLDICH D.M. and SIBLEY P.J. (Eds), Management \& Conservation of Crayfish, Proceedings of a Conference held on 7th November, 2002, Environment Agency, Bristol, pp. 169-174.

SCHÄPERCLAUS W., KULOW H., SCHRECKENBACH K., 1990. Fishkrankheiten, 5. Aufl. Berlin: Akademie-Verlag. $1123 \mathrm{p}$.

SCOTT J.R., THUNE R.L., 1986. Bacterial flora of hemolymph from red swamp crawfish, Procambarus clarkii (Girard), from commercial ponds. Aquaculture, 58, 161-165.

SÖDERHÄLL K., DICK M.W., CLARK G., FURST M., CONSTANTINESCU O., 1991. Isolation of Saprolegnia parasitica from the crayfish Astacus leptodactylus. Aquaculture, 92, 192-198.

ST-GERMAIN G., SUMMERBELL R., 1996. Identifying filamentous fungi. A clinical laboratory handbook. Star Publishing Company, Belmont, California, USA. 
TOUMANOFF C., 1965. Infections bactériennes chez les écrevisses: Entérobacteriacées, Première note: Protéoses. In-certae sedis. Bull. Fr. Pêche Piscic., 219, 41-65.

TOUMANOFF C., 1966. Infections bactériennes chez les écrevisses: Entérobacteriacées, Deuxième note: Citrobacter enterobacter, In-certae sedis. Bull. Fr. Pêche Pisci., 221, 117-133.

UNESTAM T., 1973. Significance of diseases on freshwater crayfish. Freshwater Crayfish, 1, 135-150.

VEY A., 1981. Les maladies des écrevisses, leur reconnaissance et la surveillance sanitaire des populations astacicoles. Bull. Fr. Pêche Piscic., 281, 223-236.

VEY A., 1986. Disease problems during aquaculture of freshwater Crustacea. Freshwater Crayfish, 6, 212-222.

VEY A., BOEMARE N., VAGO C., 1975. Recherches sur les maladies bacteriennes de l'écrevisse Austropotamobius pallipes Lereboullet. Freshwater Crayfish, 2, 287297.

VOGT G., 1999. Disease of European freshwater crayfish, with particular emphasis on interspecific transmission of pathogens. In: GHERARDI F. and HOLDICH D.M. (Eds), Crayfish in Europe as alien species. How to make the best of a bad situation? A. A. Balkema, Rotterdam. pp. 87-103. ISBN 9054104694. 